\title{
TEOLOGIA I URZĄD NAUCZYCIELSKI *
}

W niedawno opublikowanym sprawozdaniu o stanie posoborowej teologii i Kościoła zauważył protestancki teolog Erwin Fahlenbusch, autor cenionej pracy pt. „Kirchenkunde der Gegenwart”, że napięte stosunki pomiędzy Urzędem Nauczycielskim i teologią są ,pproblemem tkwiącym w systemie" współczesnego Kościoła katolickiego ${ }^{1}$. Kwestię tę podjął jego katolicki kolega, Hans Schilling, stwierdżając: „stosunki między wiedzą teologiczną i kościelnym Urzędem Nauczycielskim są chore $\mathrm{w}$ sensie chronicznego zakłócania kościelnego systemu komunikacji, co utrudnia konstruktywne rozwiązywanie konfliktów, uniemożliwia polaryzację i sprawia przykre, bolesne odczucie przynajmniej u znaczącej części zainteresowanych" ${ }^{2}$. Zasygnalizowaną tu problematykę uznała również za ważną grupa robocza dogmatyków i fundamentalistów posługujących się językiem niemieckim i zajęła się nią na swoim ostatnim - odbywającym się co dwa lata - posiedzeniu, które miało miejsce w styczniu br. Rzeczywistą wagę tych problemów potwierdzają bardzo konkretnie dla znawcy, historii Kościoła takie nazwiska, żeby wymienić tylko niektórych z ostatnich stu lat, jak: John Henry Newman, Herman Schell, Alfred Loisy, Henri de Lubac, Jean Daniélou, Edward Schillebeeckx, Hans Küng, przy czym dwaj z nich zmarli jako kardynałowie! Przeciwieństwem tego jest właściwe stanowisko, które papież Jan Paweł II opisał w swoim szerokie echo znajdującym przemówieniu do teologów w Altőtting, w listopadzie $1980 \mathrm{r}$. Mówiąc zdecydowanie o przyznaniu wolności i samodzielności teologii, przedstawił to następująco: „Zarówno Urząd Nauczycielski jak i teologia mają oddzielne, zróżnicowane zadania. Dlatego też nie można ich zredukować jedno do drugiego. Służą one jednakże jednej całości i przy tej właśnie strukturze muszą stale ze sobą pozostawać $\mathrm{w}$ dialogu [...]. Oby one - mimo ponawiających się okresowo

* Wykład wygłoszony przez Autora 20 marca 1981 r. na Papieskim Wydziale Teologicznym w Krakowie.

1 E. Fahlbusch, Tradition und Fortschritt. Die nachkonziliare Kirche und Theologie im Horizont neuzeitlicher Problematik und Edward Schillebeeckx: Materialdienst 31 (1980), 91.

${ }^{2} \mathrm{H}$. Schilling, Theologische Wissenschaft und kirchliches Lehramt. Erwägungen zur Therapie einer kranken Beziehung: Stimmen der Zeit 105 (1980), $294 \mathrm{n}$. 
konfliktów - kontynuowały wspólną pracę w duchu wspólnej wiary, tej samej nadziei i wszystko wiążącej miłości" ${ }^{3}$. Wyżej opisane patologiczne symptomy stają się odczuwalne dlatego, że ów stosunek odniesienia bywał rozwiązywany ciągle $\mathrm{w}$ historii teologii z korzyścią domniemywanej większej ,,jednoznaczności”, raz w kierunku absolutnej preponderancji Urzędu, jak np. w Kościele pooświeceniowym, kiedy indziej znów w kierunku uprzywilejowania teologii, jak znalazło to wyraz, przynajmniej faktyczny, w późnym średniowieczu na Sorbonie, która wówczas wydawała się identyfikować z kościelnym Urzędem Nauczycielskim. Oba kierunki mają także i dziś jeszcze swoich przedstawicieli.

Byłoby rzeczą niezmiernie interesującą prześledzić ukryte przyczyny i podstawy tych absolutyzacji oraz zbadać, jakie czynniki uczyniły je tak ostrymi $w$ ostatnich trzech generacjach. Temu szerokiemu zadaniu nie da się jednakże sprostać w krótkim wykładzie. Spróbuję raczej dać mały. komentarz do słów papieża z dogmatyczno-systematycznego punktu widzenia, i w pierwszej części określę pozycje obu badanych Wielkości [tj. Urzędu Nauczycielskiego i teologii — przyp. tł.], a następnie w drugiej części postawię pytanie o konsekwencje, które powstają z natury rzeczy, jak też w przypadkach konfliktowych.

\section{SEUŻBA DLA WIARY POPRZEZ INTERAKCJE}

Zasadnicze postawienie problemu sprowadza się do tego, że zarówno teologia jak i Urząd Nauczycielski znajdują się wewnątrz Kościoła: są one teologią i Urzędem Nauczycielskim K oś c i oła. Ich wzajemny stosunek sytuuje się zatem od samego początku w większej konstelacji relacyjnej: zadania ich są zgodne z podstawą i celem Kościoła. Kościół zaś jest „w Chrystusie niejako sakramentem, czyli znakiem i narzędziem wewnętrznego zjednoczenia z Bogiem i jedności całego rodzaju ludzkiego" 4 . Spełnia on zatem funkcję służby zarówno względem Boga, jak i względem ludzkości. Jest mu przyznana rola pośredniczenia w dialogu bosko-ludzkim. To pośrednictwo jest sakramentalne, to znaczy dokonuje się ono w widzialno-publicznych strukturach i formach. Przy tym należy zauważyć, że są one ukształtowane nie rzeczowo, lecz osobowo, ponieważ dialog sam jest personalny jako miłość pomiędzy osobowym Bogiem i wolnym, samoodpowiedzialnym człowiekiem.

Ostateczny wyraz znajduje to w Chrystusie, który jako Bóg-Człowiek

3 Papst Johannes Paul II, Ansprache bei der Begegnung mit Theologieprofessoren im Kapuzinerkloster St. Konrad in Altötting am 18. November 1980: Sekretariat der Deutschen Bischofskonferenz (Hrsg.), Papst Johannes Paul II. in Deutschland (= Verlautbarungen des Apotol. Stuhles 25), Bonn o. J. (1980), 171.

4 "Lumen gentium" 1 . 
jest kwintesencją zarówno bosko-ludzkiego dialogu, jak i praformą pośrednictwa. Nowsza teologia stara się to wyrazić, nazywając Chrystusa Prasakramentem Zbawienia.

Personalny charakter Kościoła uwidacznia się przede wszystkim w tym, że jest on miejscem obecności osobowego Ducha Bożego: „Gdzie jest Kościół, tam jest również Duch Boży; gdzie zaś jest Duch Boży - tam także Kościół i wszelka łaska, Duch bowiem jest Prawdą" - tak pisał już Ireneusz z Lyonu ${ }^{5}$. Kościół ma zatem zawsze na celu przekazanie prawdy Objawienia ludziom i to jego pośrednictwo w przekładzie jest częścią zadań Kościoła. Ponieważ pośrednictwo to jest pneumatyczne, dlatego przekaz jest radykalnie osobowy. Im bardziej Prawda musi być przepowiadana, a więc wypowiadana przez zdania i systemy zdań, tym trudniej pozwala się ona ując w te werbalne sformułowania. Prawda bowiem, w którą Duch wprowadził ludzi nie jest przecież zdaniem, ani systemem zdań, lecz Osobą, samym Bogiem-Człowiekiem.

Osobowa prawda może być przepowiadana tylko osobowo; nie dowodzi się jej, ale ją się poświadcza. Jeżeli więc Kościól ma przepowiadać Jezusa Chrystusa, powinien dla tej prawdy złożyć całe świadectwo. Ma to miejsce wtedy, gdy jego członkowie wzięci bądź to pojedynczo, bądź we wspólnocie, wyznają wiarę. II Sobór Watykański, odwołując się do starych przekazów, ponownie podkreślił, że ,zmysł wiary całego ludu" (sensus fidei totius populi) uczestniczy w prorockim urzędzie Jezusa Chrystusa i dlatego nie może błądzić. Kościół jednak - jako Ciało Chrystusa - jest organizmem posiadającym strukturę i dlatego to świadectwo konkretyzuje poprzez sieć osobowych posłannictw. Już Nowy Testament zna różnorodne i zróżnicowane urzędy przepowiadania, a to: apostołów, proroków, nauczycieli, pasterzy, ewangelistów (por. Kor 12, 8-10; Ef 4, 11 n). W dalszej historii Kościoła powstają różne instancje przekazu i ich przedstawiciele. Ta wielość jest jednakże uporządkowana, stąd też nie wszyscy mają te same zadania. Niezaprzeczalnie pierwsze miejsce zajmuje świadectwo $\mathrm{Pisma}$ S wi ̨̇tego, które nie jest przecież martwą księgą, lecz kwintesencją apostolskiego przepowiadania i dlatego stanowi normatywne świadectwo historycznego Objawienia Bożego. Ponieważ Duch Boży natchnął nie tylko autorów Pisma Św. lecz na jego podstawie - wprowadza wszystkie generacje w prawdę, do źródeł aktualnego świadczenia o wierze należy również przepowiadanie wiary przez minione pokolenia: Tr a d y c j a jest więc także źródłem wiary. Będąc na skutek apostolskiej sukcesji powiązana z pierwszymi świadkami sprawia, że wewnątrz każdorazowej generacji biskupi, a w ich kolegium papie ż, mają zadanie autentycznego świadczenia o wierze.

5 Adv. haer. III, 24, 1 (wyd. Harvey II, 132). 
Ze względu jednak na swe na stałe włączenie w cały lud Boży mogą oni tylko w harmonii z nim spełniać swoje zadanie. Przedstawiciele Urzędu Nauczycielskiego nie są więc twórcami, lecz współsłuchaczami biblijnej wiary. Kwalifikacja ich różni się od kompetencji wiernych i jest określona nie tylko przez chrzest i bierzmowanie, lecz także przez sukcesję, święcenia, soborowość i (u biskupa Rzymu) prymat. Jednakże treściowo znajdują się oni — podobnie jak wszyscy wierni - w zasięgu oddziaływania Tradycji i rozwijającej się Ewangelii. Wśród tych innych wiernych t e ologow i e mają sobie właściwe, szczególne miejsce. Osobowa wiara jest wolnym, całkowicie ludzkim przyjęciem dokonanego w historii - zwłaszcza w Jezusie Chrystusie — zbawczego Objawienia Bożego. Tym samym rozum człowiieka jest istotnie wezwany i powołany. Kardynał Joseph Ratzinger zwrócił uwagę na konsekwencje, jakie wynikają z Janowego określenia Jezusa jako Logos. Dochodzi w nim bowiem do głosu przekonanie, ,że w chrześcijańskiej wierze to co rozumne, sama głębia rozumu, posiada pierwszorzędne znaczenie" " . Rozum i wiara pozostają w korelacji, która nie daje się oddzielić. Dlatego też osobowy charakter chrześcijańskiego przepowiadania zbawienia czyni naukę samą z. siebie wolną, to znaczy tworzy system ustalen, w których wiara rozumnie się wypowiada i rozum uznaje świadectwo wiary za zapowiedź ludzkiego zbawienia. Według słów kardynała cechą chrześcijańskiej wiary jest to, ,że się jej podstawę i jej treść usiłuje zrozumieć i właśnie to przedsięwzięcie nazywamy teologią, dokładniej: mówimy o teologii, jeżeli to przedsięwzięcie dokonuje się w uporządkowanej formie według zbiorowo uznanych.i uzasadnionych reguł, które nazywamy metodą" ". Dzięki temu otrzymuje wszakże naukowa teologia samodzielną funkcję w Kościele, która przez nikogo innego nie może być przejęta w naszkicowanej komunijnej sieci.

W całości procesu kościelnego pośredniczenia istnieją zatem różne i zaopatrzone w zróżnicowane funkcje Wielkości, a mianowicie: P is mo Św., Tradycja, Urząd Nauczycielski Kościoła, teologia iświadectwowiary dawane przez wiernych. Tworzą one razem jeden jedyny system. W ramach naszego tematu zasadnicze pytanie brzmi: jak się mają do siebie wzajemnie te Wielkości? Odpowiedź jest już w swoich elementach przygotowana. Brzmi ona: dzięki wspólnemu zadaniu, zakorzenionemu w istocie Kościoła jako podstawowego Sakramentu Zbawienia, powinny te Wielkości znajdować się względem siebie w nierozwiązalnej korelacji, aby słowo Boże poprawnie rozumieć, wiernie wykładać i przepowiadać wszystkim ludziom. Jedne

${ }^{6}$ Kard. J. Ratzinger, Theologie und Kirchenpolitik: Internationale kath. Zeitschrift $9(1980), 425$.

7 Tamże, 426. 
z tych Wielkości oddziaływają na inne w żywej interakcji, ale skutecznie zbawcze funkcjonowanie nie jest gwarantowane ani przez poszczególne, ani wszystkie razem wzięte Wielkości, lecz jedynie przez Ducha Świętego. Każda $\mathrm{z}$ tych Wielkości oddziaływa na inne zarówno aktywnie, jak i receptywnie, a w tym procesie cały Kościół staje się wspólnotą w działaniu i przyjmowaniu Słowa Bożego dla ludzi, a więc właśnie Sakramentem Zbawienia. W strukturze tego procesu wszakżel poszczególne, działające w nim Wielkości nie są równe, lecz zróżnicowane. Zróżnicowanie to jednakże nie jest jeszcze hierarchią. W tym bowiem hierarchicznym odniesieniu jedna $\mathrm{z}$ tych Wielkości posiada szczególne znaczenie, nie dające się przez nic a nikogo zastąpić. Kościelny proces pośredniczenia jest więc tak ułożony, że jeden warunkuje drugi i nikt nie jest całkowicie nie uwarunkowany.

Charakterystyczne dla stosunku, jaki istnieje pomiędzy teologią i Urzędem Nauczycielskim jest to, że powinno się opisywać go jako p a r tnerstwo, a nie w kategoriach hierarchologii. Przez partnerstwo rozumiemy - przy podstawowej równości - także nie dającą się usunąć różnicę. Dokładniej teologicznie można by to tak powiedzieć: stosunki obu tych Wielkości są częścią i odzwierciedleniem owej braterskiej c o mm un i o, którą jest Kościół zgodnie z wolą Chrystusa i w coraz większym stopniu powinien nią być. Ostatni sobór podkreślił to dobitnie i w sposób nie dający się przeoczyć. Urząa Nauczycielski i teologia mają zróżnicowany autorytet i kompetencje. Jednakże przez to Urząd Nauczycielski nie staje się producentem, a teologia wiążąco-dowodzącą instancją wiary. Obie te Wielkości stoją — jak to podkreślił Jan Paweł II — w równej służbie dla wiary. Z tego względu ich wzajemny stosunek powinien się sprowadzać do współdziałania.

\section{ZASADY FUNKCJONOWANIA PARTNERSTWA}

Postarajmy się teraz w kilku tezach sformułować niektóre wytyczne ukazujące wnioski, jakie wypływają z przedstawionego stanu rzeczy.

(1) Kompleksowy zespół odniesień, w którym znajdują się teologia i Urząd Nauczycielski, wskazuje na elementy wspólne dla tych obu Wielkości i na to, co je odróżnia.

Elementy wspólne dla tych Wielkości polegają na równym związaniu ze Słowem Bożym, na konstytutywnym przekazie wiary i na zmyśle wiary wiernych, co służy zarówno spełnianiu w równym stopniu zadania dotyczącego strzeżenia, wyjaśniania i bronienia wiary chrześcijańskiej, jak również wypełnianiu służby w Kościele kierowanym przez Ducha, a to jednocześnie sprawia, że tak teologia jak i Urząd Nauczycielski mają jednocześnie charakter urzędu i charyzmatu. 
$\mathrm{R}$ ó ż $\mathrm{n}$ ą natomiast jest moc wiążąca wypowiedzi. Urząd Nauczycielski potwierdza wiarę autorytatywnie, teologia zaś argumentująco. Następnie, różna jest podstawa autorytetu: wypowiedzi Urzędu Nauczycielskiego są autentyczne na podstawie apostolskiej sukcesji, w której poszczególny biskup znajduje się przez swoje święcenia, podczas gdy wypowiedzi teologiczne - jako argumenty, które je uzasadniają - mają całkiem inną wagę. W końcu obie te Wielkoŝci różnią się z racji pastoralnych akcentów. Urząd Nauczycielski Kościoła przede wszystkim, choć nie wyłącznie, reaguje zajmując się zabezpieczeniem wiary $\mathrm{w}$ sporach danego czasu, natomiast teologia stara się głównie, choć także nie wyłącznie, w danym czasie wiarę aktywnie przedstawiać i rozwijać.

(2) Partnerskie stosunki są z natury dy n a miczn e. Owszem, dochodzi w nich do napięć a nawet konfliktów. Nie są one jednakże żadnym nieszczęściem, lecz znakiem witalności. Czymś niedobrym stają się one dopiero wówczas, jeżeli błędne zachowanie ludzkie zdobywa przewagę. Ponieważ teologowie - jako nauczyciele doktryny - są grzesznikami, nie jest to wykluczone. Abstrahując wszakże od tego, dzisiejsze napięcia w stosunkach teologii i Urzędu Nauczycielskiego są powodowane głównie przez rozbieżność między dwoma dobrami, które mają dla Kościoła życiowe znaczenie. Są to: identyczność społecznego organizmu postulująca zachowanie i umocnienie kościelnej jedności oraz powszechne posłannictwo Kościoła dążące do ekspansji katoli ck óści, a więc przyjęcia duchowej i światowej wielkości. Podczas gdy Urząd Nauczycielski za swoje główne zadanie uważa zachowanie jedności, teologia z kolei jako swoje główne zadanie przyjmuje zabezpieczenie katolickości. W obecnej chwili nie widać jednak jasno jakby obie te sprawy w równej mierze dało się zrealizować. W związku z tym stosunek pomiędzy Urzędem Nauczycielskim i teologią znamionują zauważalne napięcia. W każdym razie dysharmonia ta dopóki tylko w poszczególnych przypadkach nie ukazuje się jako przeciwieństwo, nie jest dysharmonią pomiędzy prawdą i fałszem, lecz pomiędzy dwoma interpretacjami i rozłożeniem akcentów. Kościelna jedność bowiem, która jest w sobie katolicka - a katolickość to powszechność - oznacza w tym samym nastawienie $\mathrm{w}$ pełni na zwrot $\mathrm{w}$ kierunku jedności. Aktualne obecnie napięcia nie przeciwstawiają sobie Urzędu Nauczycielskiego i teologii, lecz wskazują, że działanie obu tych Wielkości jest zbieżne względem siebie.

(3) P o śr e d n i c t w o i zjednoczenie pomiędzy tymi dwoma Wielkościami jest $\mathrm{z}$ tego względu możliwe zarówno od strony sprawy (wiary) jak i okoliczności. Są jednak przy tym s z c z e góln e war unki, które winny być zachowane, ażeby partnerstwo się udało.

Tak teologia, jak i Urząd Nauczycielski spełniają z reguły swoją służbę świadczenia wiary przez formułowanie z d ań, w yra ż a ją- 
cych doktrynę. Te poświadczające wiarę zdania mają wszakże określoną specyfikę. Według $\mathrm{Grzegorza}$ z Nazians u zbawienie znajduje się nie w wyrażeniach, lecz $\mathrm{w}$ rzeczy ${ }^{8}$. Jesteśmy zatem w każdej wypowiedzi o wierze zmuszeni „to, co się nie da sformułować ograniczonymi środkami naszej mowy, wypowiedzieć" - myśl, którą już Hilary z P oitiers sformułował ${ }^{9}$. Tym samym jednak każda mowa o wierze jest już z góry negatywna w sensie „ewidentnej bezradności” rozumienia przez nas boskiego misterium ${ }^{10}$. Jest ona dalej nie tylko otwarta, lecz i stale potrzebna. Ponadto jest ona być może faktycznie niekiedy także w tyle względem współczesnej świadomości, ponieważ nie całkiem uwzględnia jej chrześcijańskie możliwości i apele, działając nadal jeszcze $\mathrm{w}$ horyzontach myślowych przeszłości. Urząd Nauczycielski przez długi czas nie uznawał chrześcijańskiej doniosłości tematu wolności religijnej i ekumenizmu; niektórzy mówią dzisiaj, że tak samo rzecz się ma odnośnie problemu kobiety, czy podstawowych praw chrześcijan w Kościele. Również i w tym ma swoje źródło spór wśród teologów wywołujący tak często zamieszanie.

(4) Partnerska współpraca zakłada u w z g lę d nie ni e ró żn y ch ok oliczności w stosunku do Urzędu Nauczycielskiego i teologii. Jeżeli idzie o Urząd $\mathrm{Nauczycielski}$ to należy mieć następującą rzecz na uwadze:

- Według Konstytucji o Kościele II Soboru Watykańskiego Urząd Nauczycielski ma do spełnienia zadanie m od e r a t o $r a^{11}$. Służy on jedności i rozumieniu wiary, kiedy proponuje wiążące sformułowania dla jej określenia (artykulacji). W każdym razie tego rodzaju formuły słowne muszą być zrozumiałe i wiarygodne. To nie oznacza, żeby chrześcijańską wiarę pozbawić znamienia krzyża i jej sprzeciwu względem świata. Jednakże skandal krzyża nie ma nic wspólnego ze skandalem hermetycznego języka sakralnego, który dla większości żyjących ludzi nie jest zrozumiały.

- Urząd Nauczycielski jest także p r o motor e m wiary. Dlatego powinien on służyć autentyczną pomocą orientacyjną umacniającą wspólnotę wiary. Tak nie jest z pewnością, jeżeli jego działalność przypomina tylko funkcję hamulca, a nie okolicznościowo używanego pedału gazu (Gashebel) w samochodzie. Pasterze nie tylko strzegą, lecz także prowadzą do nowych pastwisk.

- Urząd Nauczycielski jest wreszcie stróżem wiary. Służy on uzgadnianiu doświadczenia wiary i tym samym wzmacnia katolickość

8 Gregor v. Nazianz, or. 43, 64 (PG 36, 588).

${ }^{9}$ Hilarius v. Poitiers, de trin. 2, 2 (PL 10, 51).

$10 \mathrm{~J}$. Ratzinger, Einführung in das Christentum, München 1968, 133. $23,25$.

11 „Lumen gentium” 27. Por. tamże użyte pojęcia Promotor 23, 37, Schützer 
Kościoła, zwłaszcza kiedy broni Kościół przed partykularyzmami i koryguje je. Domaga się możliwości wydawania ostatecznego osądu, przez który pojedynczy akt wiary staje się aktem wiary w Kościele (s. 9). Ostateczna obowiązywalność - ze względu na specyfikę mowy o wierze nie oznacza wszakże zamknięcia refleksji. Wiara nie jest strzeżona, kiedy zostaje sformalizowana, lecz gdy dzięki korekturom Urzędu Nauczycielskiego budzi nowe rozumienie. Jedność, której należy strzec - jako jedność komunijną - jest otwartą jednością.

(5) W partnerskiej współpracy z Urzędem Nauczycielskim t e o log i a powinna uwzględniać następujące ok oli czności:

- Jej zadanie w Kościele otwiera rozumienie wiary w kierunku zbawienia ludzi. Do tego powinna ona odsłaniać i pogłębiać wszystkie dostępne dane. Z tego powodu nie może pomijać pozycji Urzędu Nauczycielskiego, ale i nie może się dać przez niego tylko określać. Praktycznie oznacza to: założenia zawodu teologicznego są zarówno ,immanencją w systemie", jak i odwagą oraz gotowością do ryzyka. Jan Paweł II powiedział w swoim, cytowanym już przemówieniu: „Naukowe i tym samym teologiczne poznanie potrzebuje odwagi w narażaniu się i cierpliwości dojrzewania. Ma ono własne prawa, których nie powinno się narzucać z zewnątrz" ${ }^{12}$.

- Zbawienie ludzi dokonuje się w czasie i świecie, w którym żyją. $\mathrm{Z}$ tego względu teologia tylko wtedy spełnia skutecznie swoją służbę wierze, kiedy uwzględnia horyzont dzisiejszych ludzkich i chrześcijańskich doświadczeń i unaocznia rezultaty kościelnej świadomości. Papież wyraźnie napomniał teologów: „zwracajcie uwagę dokładnie na pytania i potrzeby współczesnego człowieka", ponieważ praca teologa jest - jak to powiada on, powołując się na św. Tomasza z Akwinu „również aktem miłości względem człowieka" ${ }^{13}$.

Jeżeli teologia przez swoje szczególne zadania ma pośredniczyć w mowie o wierze i doświadczeniu świata, przysługuje jej istotnie - rzecz zrozumiała - funkcja krytyki. Partykularyzmy istnieją wszędzie, także u przedstawicieli Urzędu Nauczycielskiego. W czasach Nawmana wydało się im właśnie niebezpieczne podkreślenie zmysłu wiary u wiernych. Dopiero II Sobór Watykański wniósł tu pewną korekturę. Wskazania apostolskiej Konstytucji „Veterum Sapientia” z 1962 r. były z całą pewnością dalekie od rzeczywistości, gdy chciały dobrą znajomość łaciny uczynić wstępnym warunkiem dopuszczenia do kapłaństwa. Przykłady można by mnożyć. Wedle wypowiedzi biskupów niemieckich z r. $1967 \mathrm{w}$ każdym razie jedno jest pewne, ,że mogą się zdarzać i zdarzały się błędy kościelnego autorytetu nauczycielskiego przy sprawowaniu jego urzę-

12 Tamże, (przyp. 3) 168.

13 Tamże, $168 \mathrm{n}$. 
du" ${ }^{14}$. Nie powinno się tego ani zakładać z góry, ani też i wykluczać, kiedy Urząd Nauczycielski przemawia. Należy jednak wziąć pod uwagę, że krytyka nie jest identyczna z wrógością, lecz może być także czynem autentycznej miłości.

(6) Urząd Nauczycielski i teologia nie mogą się be z siebie wzajemnie obe jść. Urząd Nauczycielski bez teologii nie jest zdolny skutecznie i współcześnie do świadczenia o wierze; teologia z kolei bez pomocy Urzędu Nauczycielskiego nie jest zdolna przemyśleć wiary w całej pełni. Stąd wynikają w przypadku konfliktu odpowiednie sposoby zachowania.

- Celem kościelnego działania jest zawsze zbawienie ludzi; nie jest nim zatem ani formalna pewność, ani też naukowa dokładność. Współcześnie oznacza to, że nie wolno z powodu jednej owcy zostawiać na pustyni innych 99 zgłodniałych i spragnionych. Współpraca i zgodność pomiędzy teologią i Urzędem Nauczycielskim stają się więc postulatem fundamentalnego zadania misyjnego Kościoła. Proszę mi pozowolić jeszcze raz zacytować papieża Jana Pawła II: „Człowiek wierzący ma prawo wiedzieć na co się zdaje we wierze. Teologia musi pokazać człowiekowi, gdzie znajduje ostatnie oparcie. Dlatego właśnie został dany Kościołowi Duch Prawdy. Urząd Nauczycielski jest tylko po to, aby ustalić prawdę Słowa Bożego zwłaszcza tam, gdzie jest'ono zagrożone poprzez zakwestionowania i nieporozumienia" ${ }^{15}$.

- Najważniejsze założenie dla partnerskiej współpracy posiada samookreślenie się obu Wielkości. Urząd Nauczycieḷski i teologia muszą pozostawić wiarę otwartą na misterium. One nie powinny stwarzać barier, lecz je usuwać; powinno im zależeć nie na ostatnim słowie, lecz na większym pokoju. Ten powstaje nie z przemocy, lecz na gruncie zaufania i wolności. Obie nie są pozbawione granic, lecz mają je tam gdzie misterium jednoznacznie ulega zranieniu. Wędrowanie po granicy jednak nie jest jeszcze przekroczeniem granicy. W sytuacji wielu współczesnych kierunków myślenia granice są mniej jednoznaczne niż dawniej; to wszakże nie jest tylko niebezpieczeństwem, ale oznacza także szanse większej katolickości.

- Zaufanie i wolność umożliwiają dialog. Jest on, jak twierdzą ojcowie II Soboru Watykańskiego, wyróżniającą cechą Kościoła Chrystu$\mathrm{Sa}^{16}$.

- Dialog zawsze argumentuje, a nie interweniuje. Tak więc teolog może od Urzędu Nauczycielskiego domagać się pewnego zaufania właś-

14 Schreiben der deutschen Bischöfe an alle, die von der Kirche mit der Glaubenverkündigung beauftragt sind, Trier 1967, 12.

15 Tamże, (przyp. 3) 171.

16 „Gaudium et spes" 92. 
nie $\mathrm{z}$ tego tytułu, że Urzędowi Nauczycielskiemu bezsprzecznie przypada ostateczny osąd. Teolog potrzebuje wolności zarówno dla swojej pracy $\mathrm{w}$ obrębie Kościoła jak i w domu nauki. Tu trzeba zaliczyć także „wolność do błędu". Jak każda wiedza, może także i teologia postępować naprzód zawsze tylko na sposób „, tria 1 a n d e r r or”, poprzez próby i pomyłki. I odwrotnie także Urząd Nauczycielski ma prawo domagać się wyjścia naprzeciw z zaufaniem. Celem jego służby jest jedność wszystkich grup. Oznacza to, że musi on w krytycznej sytuacji wypowiedzieć autentyczne słowo, które także teologia powinna przyjąć.

W tak krótkim czasie, który mieliśmy do dyspozycji, nie można zamknąc wszystkich skomplikowanych rozważań wiążących się z poruszanym tematem; muszą one być przerwane. Dokonane przemyślenia będą miały wtedy swój sens, jeżeli spowodują dalsze próby zajęcia się omawianą problematyką. Istnienie Urzędu Nauczycielskiego w Kościele znajduje zawsze swój najgłębszy sens w sformułowaniu zamieszczonym w drugim liście do Koryntian: „Przybyłem... nie żeby okazać nasze w $\nmid$ a d ztwo nad was zą wiar ą, bo przecież jesteśmy współtwórcami waszej radości" ( 2 Kor 1, 24). Z kolei dewizę teologii wyznacza napomnienie autora pierwszego listu św. Piotra: „B ą d ź c i e z a w s z e g otowi do obrony wobec każdego, kto domaga się od was uzasadnienia tej nadziei, która w was jest" (1 P $3,15)$. Jeżeli to Pawłowe i Piotrowe nauczanie znajduje właściwy oddźwięk w działaniu, wówczas wzrasta w Kościele i przez Kościół radość i nadzieja w świecie. Nic bowiem, jak właśnie to, nie jest pilniejsze, nic bardziej zgodne z misyjnym posłaniem. W ten sposób Ewangelia nakłada teologii i Urzędowi Nauczycielskiemu oraz wszystkim ludziom w Kościele obowiązek, aby stała się ona dla wszystkich radosną nowiną.

Z niemieckiego tłumaczyli: Adam Kubiś - Krystyna Przyborowska 